\title{
Centennial Campaign Kick-Off
}

The Association's Centennial Campaign was officially kicked off amid the 750 panels and roundtables and the 250 business meetings and receptions that occupied the record-breaking number of participants at APSA's Annual Meeting in Boston. The five-year effort to endow professional opportunity programs and establish a research center in Washington, DC, for visiting scholars from the United States and abroad was introduced to APSA's general membership accompanied by an extremely positive progress report. Addressing the attendees at the kick-off reception, Campaign $\mathrm{Co}$-Chairs Dale Rogers Marshall and Jack Peltason reported that the Centennial Campaign had already raised approximately $\$ 1.7$ million of its $\$ 3$ million goal.

The money already raised has come from internal transfers, earnings on designated investments, and well over $\$ 600,000$ in gifts from the Association's members and friends. Rogers and Peltason announced several major gifts, including a gift of $\$ 75,000$ from the estate of Leo Shrifin and a pledge of $\$ 25,000$ from the Huang Hsing Foundation and its director, Chun-tu Hsueh, in support of Centennial Center residencies for international scholars. Earlier in the week at the annual Honor's Reception, APSA Executive Director Catherine Rudder announced a major gift from former APSA president Pendleton Herring and Jill Herring in support of the Association's collection of political art and prints. The record of generosity of APSA's members and friends is presented in the Campaign Honor Roll printed in this issue of $P S$.

Also appearing at the Centennial Reception, APSA's President-Elect Matthew Holden Jr. observed, "The outpouring of support even before the Campaign was made public is heartening." He went on to say, "We have come far in an extraordinarily short time, but we still have far to go. It is for each of us to decide whether to support the Campaign's objectives and the size of that support. One need not be well-off to give since pledging makes giving relatively easy. Nor should one be dissuaded from giving because they feel their gift is too insignificant or less than they would like to give." Reminding the attendees of the effort of the 214 founding members of the Association, PresidentElect Holden added, "Reaching the Campaign's goals are not the responsibility of a few community-spirited individuals. Expanding opportunities for current and future generations of political scientists is our collective challenge. If each of us is not committed to our discipline's future, then why should anyone else be?"

The evening ended with a drawing for a vacation of four days and five nights at any Marriott Hotel, which was contributed by the Marriott Corporation, and two USAir tickets for travel in the United States, Canada, or Caribbean. Martin O. Heisler was the lucky winner of the vacation getaway.

(Opposite Page) 1998 Annual Meeting: A Look Back. Clockwise from upper left: Representative Christopher Shays (R-CT) delivers the 1998 Pi Sigma Alpha Lecture; Jack Peltason, co-chair of the APSA Centennial Campaign, welcomes attendees to the Centennial Kick-Off reception; 1998 APSA President M. Kent Jennings; Daniel Press, University of California, Santa Cruz, discusses his poster presentation; 1998 Program Chair Virginia Sapiro, University of Wisconsin, Madison; Meeting attendees review the latest offerings from publishers at the exhibition hall.

\section{Campaign Supports International Scholars}

The Huang Hsing Foundation and its president, Chun-tu Hsueh, have joined the Centennial Campaign effort and generously endowed research residencies for international scholars at the Centennial Center. The pledge of support helps to emphasize the international scope of the Centennial Campaign. Scholars from abroad, especially those from the Peoples Republic of China, will benefit from the Huang Hsing-Chun-tu Hsueh Endowment.

Along similar lines, APSA President-Elect Robert Keohane and Nannerl Keohane, president of Duke University, have made a generous gift to begin a new restricted endowment for the benefit of international scholars. The endowment will be known as the James Bryce Endowment, in honor of Sir James Bryce, author of The American Commonwealth (1888). The American Commonwealth was the principal textbook on American government in the American political science curriculum at the beginning of the twentieth century. Bryce further distinguished himself as APSA's fourth president (1908), and by serving as Great Britain's Ambassador to the United States. Income from the Bryce Fund will support research residencies in the Centennial Center for APSA members coming from abroad to pursue their own research projects.

APSA members are encouraged to contribute to the Bryce Fund to advance the internationalization of American political science. 